\title{
The Urgency of the Omnibus Law in Accelerating the Harmonization of Legislation in Indonesia
}

\author{
Rodiyah $^{1}$, Indah Sri Utari ${ }^{2}$ \\ \{rodiyah@mail.unnes.ac.id ${ }^{1}$, indahsuji@mail.unnes.ac.id \\ ${ }^{1,2}$ Faculty of Law, Universitas Negeri Semarang, Semarang, Indonesia
}

\begin{abstract}
Empirical facts show that there are 42 thousand laws and regulations in Indonesia. As a result, there are many overlapping regulations, both in the same hierarchical level and / or with the regulations below. This condition makes the Omnibus Law urgency in statutory regulations. Omnibus Law is one of the important alternative choices by harmonizing legislation. The Omnibus Law is an umbrella law because it regulates thoroughly and then has power over other rules. Stufenbau theory, the legal system and the operation of law are the basis for analysis that the harmonization of the Omnibus law becomes a protector for executives (implementing legislation) who will innovate and create divine justice in economic progress and investment. The implementation of the concept of omnibus law in Indonesia is a hierarchical order of linear legislation with Law Number 15 of 2019 concerning the Formation of Legislations. The form of a law is not a basic law, but a law which is equivalent to other laws, which all or part of the provisions are amended or abolished by making new norms.
\end{abstract}

Keywords: omnibus law; harmonization of legislations; accelerating; legal drafting

\section{Introduction}

Since Indonesia's independence, Indonesia has gone through various government regimes. From the Old Order government, the New Order to the Reform Order. Changes from time to time, accompanied by changes in the president and cabinet of government clearly resulted in the birth of many laws and regulations in accordance with the context of the problems and challenges at that time. Over the past 74 years of independence, the increasing number of regulations produced has caused its own problems, such as disharmony and overlapping regulations. As a further result, there are also many conflicts over policies or authorities between one ministry/agency and other ministries/agencies, and also between the Central Government and the Regional Government.

Unfortunately, disharmony and overlapping of these regulations not only makes the government unable to move swiftly and responsively to face problems and challenges that arise, but also has an impact on hampering the implementation of development programs and worsening the investment climate in Indonesia.

Considering that the production of regulations, starting from the level of laws throughout Indonesia's independence, has accumulated and has led to the phenomenon of "hyper-regulation", so every government organizer intends to make innovations or breakthroughs, it is certain that there will be a clash with statutory regulations. Meanwhile, if the revision of legislation is to be carried 
out conventionally, it is easy to predict that it will take a very long time to harmonize and synchronize the many existing regulations.

At the same time, the challenges of the digital society ecosystem era are in front of us. Indonesia should not be entangled in formal procedures for long. A policy breakthrough in the law drafting process must be born immediately. Based on this urgency, the only way to quickly simplify and uniform regulations is through the Omnibus Law scheme.

The definition of Omnibus Law comes from the words omnibus and law. The word omnibus comes from the Latin word omnis, which means "for all" or "many". When coupled with the word law, which means law, the Omnibus Law can be defined as the law for all.

The debate regarding the Omnibus Law as the main means of structuring regulations surfaced when the Omnibus Law method, which was previously not widely known in Indonesia-a country with a Continental European legal system, was used in the preparation of the Draft Law (RUU) which became the 2020 Priority National Legislation Program. There are two bills in the 2020 Priority National Legislation Program that use the Omnibus Law method, namely: the Omnibus Law proposed by the Government and the Bill on Taxation Provisions and Facilities for Economic Strengthening (Omnibus Law) proposed by the Government [1][2]

Regulatory reform policy through the implementation of the Omnibus Law in Indonesia, is certainly not something the government does carelessly. Many considerations made by the government why choose the Omnibus Law method in carrying out urgent regulatory reforms. Various efforts to encourage increased investment were made by the government, but in the midst of the era of the Fourth Industrial Revolution, various policies that have been taken by the government to improve the investment climate have not attracted investors to invest in Indonesia.[2] $[4][5]$

\section{Method}

This study uses a hermeneutic approach and in hermeneutically, that is, analyzing the content and context of policy material. The research will interpret the meaning of the articles in the policy so that it will get the correct meaning sociologically, philosophically and juridically [3].

\section{Results and Discussion}

\subsection{Stufenbau Theory in the Formation of the Omnibus Law}

Omnibus Law is something new in Indonesia even though other countries have implemented such as the United States (The Omnibus Act of June 1868, The Omnibus Act of February 22,1889), Canada (Criminal Law Amendment Act, 1968-69), the Philippines (Tobacco Regulation Act of 2003) and 39 countries that adopted the Omnibus Law in terms of personal data protection released by Privacy Exchange.org (A global information resource on consumers, commerce, and data protection worldwide National Omnibus Laws), such as Argentina, Australia, Austria, Belgium, Canada, Chile, Czech Republic, Denmark, Estonia, Finland, France, Germany, Greece, Hungary, Iceland, Ireland, Israel, Italy, Japan, Latvia, Liechtenstein, Lithuania, Luxembourg, Malta, The Netherlands, New Zealand, Norway, Poland, Portugal, Romania, Russia, Slovak Republic, Slovenia, Spain, Sweden, Switzerland, Taiwan, Thailand, and United Kingdom. [30][31]

The definition of Omnibus Law starts from the word Omnibus. The word Omnibus comes from Latin and means for everything. In Bryan A. Garner's Black Law Dictionary Ninth Edition it mentions omnibus: relating to or dealing with numerous object or item at once; including many things or having various purposes, which means relating to or dealing with various objects or items at once; include many things or have multiple purposes. When coupled with the word Law, it can be defined as law for all. [15][18]

In the hierarchy/order of laws and regulations in Indonesia as regulated in Law Number 12 Year 2011 concerning the Formation of Legislation, the concept of Omnibus Law has not been included as one of the principles in the source of law. However, the harmonization of laws and regulations in Indonesia is continuously carried out to minimize conflicts of legislation. The Indonesian legal 
system that adheres to the Civil Law system is one of the reasons why the concept of Omnibus Law is unknown. [15]

From the problem of harmonization of laws and regulations in Indonesia, the government needs to take a legal breakthrough to fix regulatory conflicts. The demand for improvement and rearrangement of overlapping laws and regulations in Indonesia is very urgent. One of the Omnibus Law ideas is likely to be applied in Indonesia along it is given space and a legal foundation. [15][16]

Omnibus Law is not new in the world of legal science globally, it is just that in Indonesia it is very necessary to fix overlapping laws and regulations. The process of harmonizing statutory regulations in addition to the above obstacles also takes a long time. With the concept of Omnibus Law, regulations that are considered irrelevant or problematic can be resolved quickly.

However, some academics also think that if the Omnibus Law concept is enforced, it is against the principles of democracy, because the concept of Omnibus Law is considered anti-democratic. However, the biggest question, do we have to continue to allow conflicts of laws and regulations? The government needs to make a legal breakthrough to be able to solve the overlapping problem of several laws and regulations. [20][21][22]

The order of laws and regulations in Indonesia must be revised and provide room to apply the Omnibus Law concept. Moreover, the current condition of policy makers can easily be criminalized by law enforcement officials. The understanding of the legal knowledge of the majority of law enforcement officers wears the perspective of legal positivism, so it is difficult to provide room for policy makers in this case officials to exercise discretion. Often discretion made by policy makers leads to crimes because they are accused of committing corruption. [20][21][22]

The aims of abstract law in the midst of a complex society can only be realized through complex organization. This means that the community will accept the law's objectives. The objectives of law include creating peace and upholding justice. Thus, the public will not do street justice or vigilante justice. The legal community will fully submit to the legal process because it is able to provide a sense of legal certainty (rechtszekerheid). [23][25]

This is an irony where Indonesia as a rule of law with all its instruments aims to protect human rights and provide justice for most of its citizens which is very urgent now to "bring justice to the people" (to bring justice to the people) by resolving justice to the people properly. problems which the people deem to be resolved legally. Another problem is when the act is disliked or hated by the community because it causes harm or causes a victim. In other words, the extent to which the problem or action contradicts the prevailing values in society and society considers it appropriate or inappropriate to be punished in the context of carrying out the welfare and security of the community. [4][5][8][10]

Order and security become real things through the actions of the Police. It can be argued that law enforcement will always involve humans in it and with human behavior itself. The law cannot run alone but must be implemented by the community. These legal regulations become a social contract and provide legal certainty in society. Thus, legal awareness arises automatically along with increasing trust in law enforcement officials. The law referred to can be in the form of criminal law, civil law, family law and other fields of law. [9][10][11]

The Omnibus Law which can later be realized in the form of an integrated regulation (Omnibus Regulation) will minimize the clash of laws and regulations related to certain fields. Observing the statutory system in Indonesia, the Law resulting from the concept of the Omnibus Law can lead to the Omnibus Law because it regulates thoroughly and then has power over other rules. However, in Indonesia it does not adhere to the Umbrella Law because the position of all laws is the same. Problems that arise when examined from the perspective of the theory of legislation regarding their position, so that their position must be given legitimacy in Law Number 12 of 2011 concerning the Formation of Laws and Regulations must be amended. [10][11]

The process of forming laws and regulations from theoretical studies related to the existence and enforcement of laws in society is known as Legal Development (rechtsbeoefening). This activity includes activities in shaping, implementing, implementing, discovering, interpreting, studying, and teaching law. The development of law is distinguished in the Development of Practical Law and the Development of Theoretical Law. [10][11] 
The adoption of Practical Law is a human activity with regard to realizing the law in the realities of everyday life in a concrete manner. These activities include Legal Formation, Legal Discovery and Legal Aid [10][11]

Meanwhile, The Development of Theoretical Law is also known as Theoretical Reflection on law, which is an activity of reason to gain intellectual mastery of law or scientific understanding of law, namely methodically systematic - logically rational. Development of Theoretical Law is divided into 3 (three) types based on the level of abstraction or based on the level of analysis (level of analysis), namely Law Studies, Legal Theory and Philosophy of Law

There are several advantages of applying the Omnibus Law concept in resolving regulatory disputes in Indonesia, including: (1) Resolving legislative conflicts quickly, effectively and efficiently; (2) Uniform government policies both at the central and regional levels to support the investment climate; (3) Licensing management is more integrated, efficient and effective; (4) Able to break the long bureaucratic chain; (5) The increased coordination relations between related agencies because it has been regulated in an integrated omnibus regulation policy; (6) There is a guarantee of legal certainty and legal protection for policy makers.[15[16]

Meanwhile, the weaknesses in the application of this concept when applied include: (1) Opening up opportunities to be rejected at the time of plenary or in judicial review of the issued omnibus regulation policy; (2) The legislature feels "castrated" because the process of forming legislation does not involve the legislature; (3) Will affect the stability of the national legal system due to the orientation of government policies that change according to the will of the governing regime. $[22[25[26][32][33]$

\subsection{How the Omnibus Law in Indonesia Should Become an Alternative for Overlapping?}

In several countries, such as the United States, Belgium, United Kingdom, they offer solutions to problems with the emergence of conflicts and overlapping norms / regulations. If you want to fix them one by one, it will take quite a long time and a lot of money. Not to mention that the process of drafting and forming legislation on the part of the legislature often creates deadlocks or is not in accordance with interests.

This ultimately consumes energy, time, cost, and the goals to be achieved are not on target. In fact, this is added with the decrease in the level of public trust in legislative performance. For this reason, a legal breakthrough from the government is needed to solve regulatory problems

To achieve this, it is necessary to be based on strong regulations. One of the countries that adopted the Omnibus Law is Serbia. The Omnibus Law is a law adopted in 2002 that regulates the autonomous status of the Vojvodina Province which belongs to Serbia. The law covers the jurisdiction of the Vojvodina Provincial government regarding culture, education, language, media, health, sanitation, health insurance, pensions, social protection, tourism, mining, agriculture, and sports.

The Process of Law Formation Omnibus law is done in the same way as the formation of laws in general. In Article 1 number 1 of Law 12 of 2011 referred to as the Establishment of Legislative Regulations is the making of Legislative Regulations that includes the stages of planning, preparation, discussion, ratification or stipulation, and legislation. The stages of the formation of legislation are generally done as: (1) Planning Stages of drafting laws; (2) Preparation for the Formation of Law; dan (3) Submission of Draft Law.

According to Heri, the concept of the omnibus law in its manufacturing mechanism must follow the procedures stipulated in Law Number 15 of 2019 concerning the Formation of Legislation, starting from planning, drafting, discussion, to ratification. He considered, the omnibus law scheme was too sectoral and narrow. However, on the other hand, it is good for stimulating investment and exports. In fact, if the omnibus law is applied, of course, it will have a significant impact on better economic growth.

There are five steps that must be fulfilled by lawmakers in drafting the Omnibus Law. Here are five steps that the government must take to ensure that the Omnibus Law is effective and not misused, namely: First, the People's Representative Council (DPR) together with the government must involve the public in every stage of its formulation. The broad scope of the Omnibus Law 
demands that lawmakers reach out and involve more stakeholders involved. Second, the DPR and the government must be transparent in providing any information on the progress of the Omnibus Law formulation process. This absolute participation and transparency is reflected in the legislation process that has sparked recent controversy, such as the formulation of the revision of the Corruption Eradication Commission Law and the Revision of the Criminal Code. Third, compilers must map the relevant regulations in detail. Fourth, the compilers must strictly harmonize both vertically with higher regulations and horizontally with equivalent regulations. Fifth, compilers must preview before it is passed. This preview is prioritized to assess the impact that will arise from the law that will be passed. [15][16]

Furthermore, it is also emphasized that Omnibus Law is a method for making a regulation or Law which consists of many subjects or subject matter for certain purposes to deviate from a regulatory norm. The Omnibus Law differs from most draft regulations in terms of the number of content materials covered, the number of articles that are regulated (size), and finally in terms of complexity. An Omnibus Law covers almost all related material substances-reflecting integration, codification of rules whose main goal is to streamline the application of these regulations. The theoretical and practical method of Omnibus Law legislation is still not well known in Indonesia. [7][10][11][15]

In drafting a rule using the Omnibus method, it will cover almost all related material substances so that the regulation can stand alone and not depend on other regulations. Rules with the omnibus method reflect an integrated, codified rule where the ultimate goal is to streamline the application of these rules in the practices. [17[18][19]

\section{Conclusions}

Simplification of laws and regulations in the midst of overlapping legal conditions in Indonesia is one of the government's top priorities. Through the Omnibus Law, the government seeks to simplify various regulations, especially those related to the economy, environment, and investment. In the context of the Theory of Laws and Regulations, the formation of the Omnibus Law is an opportunity for harmonization of statutory rules in Indonesia. With reference to the Self-Regulating System, giving high authority to the President to regulate regulations for himself. The power of the President in making regulations is exercised to regulate both economic regulation, social regulation, and administrative regulation. The Work Creation Bill (Omnibus Law) was prepared with the consideration of supporting work copyright where it is necessary to adjust various regulatory aspects where changes to sectoral laws are partially felt to be ineffective and efficient, so that a legal breakthrough is needed through the formation of laws using the Omnibus Law method that can solve various problems in several Laws into one Law in a comprehensive manner.

\section{References}

[1]. DPR, "Program Legislasi Nasional Prioritas Tahun 2020-2024",

http://http://www.dpr.go.id/uu/prolegnas, on 15 Februari 2020).

[2]. Irma Mayasari. 2020. KEBIJAKAN REFORMASI REGULASI MELALUI IMPLEMENTASI

OMNIBUS LAW DI INDONESIA (Regulatory Reform Policy Through Implementation of Omnibus Law in Indonesia). Jurnal Rechts Vinding: Media Pembinaan Hukum Nasional, 9(1), 1-15.

[3]. Wignjosoebroto, S. (2002). Hukum : Paradigma, Metode dan Dinamika Masalahnya. Jakarta: ELSAM -HUMA.

[4]. Asian Development Bank, Jalan Menuju Pemulihan Memperbaiki iklim investasi di Indonesia, (Asian Development bank, 2005).

[5]. Rasjidi, Lili. dan Liza Sonia Rasjidi, Dasar-dasar Filsafat dan Teori Hukum, (Bandung: Citra Aditya Bakti, 2016)

[6]. Indrati, Maria Farida. Ilmu Perundang-Undangan Proses dan Teknik Pembentukannya, (Yogyakarta: Kanisius, 2007).

[7]. Fifield, Mitch. Civil Law and Justice (Omnibus Amendments) Bill 2015.

[8]. JURNAL:

[9]. Bedner, Adrian. Indonesia Legal Scholarship and Jurisprundence as an Obstacle for Transpalanting Legal Instituions, Hague Journal of the Rules of Law 5 (2013). 
[10]. Busroh, "Konseptualitas Omnibur Law dalam Menyelesaikan Permasalahan Firman Freaddy. Regulasi Pertanahan”, Arena Hukum, Vol. 10, No. 2, (Agustus 2017).

[11]. Toruan, Henry Donald Lbn. Pembentukan Regulasi Badan Usaha dengan model Omnibus Law, Jurnal Hukum to-ra, Vol.3, No. 1, April 2017

[12]. Kementerian Koordinator bidang Perekonomian Republik Indonesia, dalam FGD Persiapan Omnibus Law dengan judul : Penyiapan Omnibus Law Ekosistem Investasi (Kemudahan Berusaha)

[13]. PERATURAN PERUNDANG-UNDANGAN:

[14]. Indonesia, Undang-undang Dasar Negara Republik Indonesia tahun 1945

[15]. Indonesia, Undang-undang Nomor 12 Tahun 2011 tentang Pembentukan Peraturan Perundangundangan, TLN 5234

[16]. Indonesia, Undang- Undang Nomor 15 tahun 2019 tentang Pembentukan Peraturan Perundangundangan, TLN 6398

[17]. Indonesia, Undang-Undang Nomor 28 Tahun 2007 Tentang Perubahan Ketiga Atas Undang-Undang Nomor 6 Tahun 1983 Tentang Ketentuan Umum Dan Tata Cara Perpajakan , LN Tahun 2007 Nomor 85.

[18]. Indonesia, Undang-Undang Nomor 7 Tahun 1992 Tentang Perbankan Sebagaimana Telah Diubah Dengan Undang-Undang Nomor 10 Tahun 1998, LN Tahun 1998 Nomor 182, TLN Nomor 3790.

[19]. Indonesia, Peraturan Pemerintah Pengganti Undang-Undang Nomor 1 Tahun 2017 Tentang Akses Informasi Keuangan Untuk Kepentingan Perpajakan, LN Tahun 2017 Nomor 95, TLN, 6051, bagian menimbang huruf a.

[20]. Indonesia, Undang - Undang Nomor 23 Tahun 2014 tentang Pemerintahan Daerah, LN Tahun 2014 Nomor 244, TLN Nomor 5587, Pasal 409.

[21]. INTERNET:

[22]. Agustiyanti, Jokowi Sebut 42 Ribu Aturan Hambat RI Ikuti Perubahan Global, https://www.cnnindonesia.com/ekonomi/20171024125609-92-250596/jokowi-sebut-42-ribu-aturanhambat-ri-ikuti-perubahan-global, Selasa, 24/10/2017, diakses pada tanggal 25 November 2019

[23]. Birenbaum, David E. "The Omnibus Trade Act Of 1988: Trade Law Dialectics", < https://www.law.upenn.edu/journals/jil/articles/volume10/issue4/Birenbaum10U.Pa.J.Int\%271Bus.L.653 \%281988\%29.pdf>, diakses pada tanggal 24 November 2019.
[24]. Dewan Perwakilan Rakyat, Skema

Sektoral, http://www.dpr.go.id/berita/detail/id/26322/t/Skema+\%E2\%80\%98Omnibusw\%E2\%80\%99+San gat+Sektoral, 4 November 2019.

[25]. FNH, "Menimbang Konsepsi Omnibus Law Bila Diterapkan di Indonesia", https://www.hukumonline.com/berita/baca/lt58a6fc84b8ec3/menimbang-konsep-omnibus-lawbila-diterapkan-di-indonesia/, diakses 24 November 2019, 17.09.

[26]. Fifield, Mitch. Civil Law and Justice (Omnibus Amendments) Bill 2015, < https://www.openaustralia.org.au/senate/?id=2015-06-25.87.1>, diakses pada tanggal 24 November 2019. [27]. Rizki, Mochamad Januar. 5 Catatan Menyederhanakan Izin Investasi Melalui Omnibus Law, Senin, 14 Oktober 2019, https://www.hukumonline.com/berita/baca/lt5da3efc332c06/5-catatan-menyederhanakanizin-investasi-melalui-omnibus-law/, diakses pada jam 00:16 tanggal 14 November 2019.

[28]. Naskah akademik siap, omnibus law perizinan sudah dikirim ke Presiden, https://nasional.kontan.co.id/news/naskah-akademik-siap-omnibus-law-perizinan-sudah-dikirimke-presiden, 8 Oktober 2019 / 20:21 WIB, diakses pada tanggal 25 November 2019.

[29]. Transportation Equity Act For The 21st Century", < https://www.fhwa.dot.gov/tea21/tea21.pdf>, diakses pada tanggal 24 November 2019.

[30]. Moerdijat, Lestari. Memahami Omnibus Law, http://lestarimoerdijat.com/2019/11/22/memahamiomnibus-law/, diakses tanggal 22 November 2019.

[31]. Prabowo, Dani. Mengenal "Omnibus Law" yang akan dibahas pemerintah dan DPR, https://nasional.kompas.com/read/2019/11/29/13511951/mengenal-omnibus-law-yang-akan-dibahaspemerintah-dan-dpr?page=all, diakses pada 24 November 2019.

[32]. Warsudi, Agus. Pakar HTN Fahri Bachmid: Omnibus Law Perlu Lembaga Pusat Legislasi Nasional, https://jabar.sindonews.com/read/11563/1/pakar-htn-fahri-bachmid-omnibus-law-perlu-lembagapusat-legislasi-nasional-1571915439, diakses pada 24 November 2019
[33]. Mulyana,
Cahya.
Omnibus
Law
perlu
Tim

Khusus, https://www.medcom.id/ekonomi/makro/0k8DpE9k-omnibus-law-perlu-tim-khusus, diakses pada 24 November 2019 